\title{
Гапон В. В.
}

кандидат педагогічних наук, начальник відділу інформаційно-аналітичних систем ДНУ «Інститут освітньої аналітики», Київ, Україна, gapon@mon.gov.ua ORCID ID: https://orcid.org/0000-0001-7521-5450

\section{Барабаш О. А.}

завідувач сектору фінансово-економічної звітності ДНУ «Інститут освітньої аналітики», Київ, Україна, o_barabash@mon.gov.ua

ORCID ID: https://orcid.org/0000-0003-2545-0369

\section{ІНФОРМАЦІЙНО-АНАЛІТИЧНЕ ЗАБЕЗПЕЧЕННЯ ФОРМУВАННЯ ТА АНАЛІЗУ СТАТИСТИЧНИХ ПОКАЗНИКІВ ЗАГАЛЬНОЇ СЕРЕДНЬОЇ ОСВІТИ}

\begin{abstract}
Анотація. У статті досліджено нормативно-правові документи щодо збору та опрацювання галузевої статистичної звітності. Розроблено структуру інформаційної бази, сформованої на єдиних методологічних принципах організації статистичного спостереження, та інструментальні засоби формування зведеної статистичної звітності для подання до Державної служби статистики України. Визначено основні напрями якісних перетворень в інформаційно-аналітичному забезпеченні та удосконаленні структури й змісту статистичної звітності від закладів загальної середньої освіти. Розроблено інформаційні бюлетені щодо стану загальної середньої освіти за напрямами (мережа закладів загальної середньої освіти, педагогічні кадри, профільне навчання, мови навчання та вивчення мови як предмета, матеріально-технічне забезпечення та використання сучасних інформаційних технологій, заклади спеціальної освіти тощо).
\end{abstract}

Ключові слова: загальна середня освіта, заклад загальної середньої освіти, статистична звітність, статистичний показник, інформаційно-аналітичне забезпечення.

Рис. 4. Літ. 20.

JEL classification: I28, C10, C80, Y10.

Невпинне збільшення управлінської інформації, зростання ролі особистості та інтелектуалізація її праці, швидка зміна техніки і технологій потребують постійного розвитку та модернізації загальної середньої освіти, приведення ії стану і можливостей у відповідність з соціальноекономічними потребами суспільства. Одним із продуктивних підходів, що значною мірою спрямований на розв'язання зазначених проблем, $€$ розвиток комп'ютерних систем опрацювання статистичної звітності для забезпечення управління освітою.

Статистика загальної середньої освіти характеризується складною системою взаємозв'язків між показниками, своєрідністю методики дослідження та наявністю якісних та кількісних показників, що дозволяють поглибити аналіз на загально-

(C) Гапон В. В., Барабаш О. А., 2019 
державному й регіональному рівнях, визначити науково-методичні підходи до оцінювання діяльності та прогнозування тенденцій розвитку у цій сфері.

Отже, для успішного аналізу стану середньої освіти необхідне інформаційно-аналітичне забезпечення, розроблене на єдиних методологічних принципах організації статистичного спостереження, що забезпечить не тільки вирішення окремих питань та контроль виконання запропонованих заходів, а й будь-яке аналітичне дослідження залежно від поставлених завдань.

Окремі аспекти інформаційного та методологічного забезпечення статистичного дослідження розглядаються у працях В. Бикова [1], С. Герасименка [2], А. Головача [3], О. Ляшенка [4], 0. Осауленка [5] та ін. Актуальні питання якості загальної середньої освіти досліджували українські вчені, зокрема О. Локшина [6], Л. Лукіна [7].

Інформація про розвиток мережі закладів загальної середньої освіти (33С0), структуру й динаміку контингенту учнів і випускників, стан i використання матеріально-технічного забезпечення, структуру та якість складу педагогічних працівників, джерела надходження та напрями використання фінансового забезпечення складає основу галузевої статистичної звітності.

Метою статті $\epsilon$ аналітичне дослідження показників статистичної звітності за рівнями управління та розробка концептуальних засад створення інформаційно-аналітичного забезпечення для оцінювання стану загальної середньої освіти, що потребує вирішення таких завдань:
- визначення суб'єктів статистичної звітності в системі загальної середньої освіти;

- аналіз порядку формування та заповнення статистичної звітності на різних рівнях управління;

- удосконалення структури та змісту первинної статистичної звітності;

- розроблення математичної моделі та комп'ютерної технології узгодження статистичних показників;

- розроблення методологічних підходів до побудови інформаційного середовища;

- формування системи показників та рейтингових індикаторів для моделювання та оцінювання стану загальної середньої освіти;

- формування статистичних та інформаційно-аналітичних збірників щодо стану загальної середньої освіти на регіональному рівні;

- підготовка зведеної галузевої статистичної звітності для подання до Державної статистичної служби України.

Нормативно-правовим забезпеченням для збору та опрацювання форм галузевої статистичної звітності є закони України «Про освіту» [8], «Про державну статистику» [9], «Про загальну середню освіту» [10] та Указ Президента України «Про національну стратегію розвитку освіти в Україні на період до 2021 року» [11].

Наказами Міністерства освіти і науки України затверджені форми статистичної звітності 3Н3-1 «Звіт денного закладу загальної середньої освіти на початок навчального року», 76-РВК «Зведений звіт денних закладів загальної середньої освіти на початок навчального року» [12]; 3НЗ-2 «Звіт вечірньої (змінної) школи», 
3В-1 «Зведений звіт вечірніх (змінних) шкіл» [13]; 83-РВК «Звіт про чисельність та склад педагогічних працівників закладів загальної середньої освіти» [14]; таблиці Д-4 «Відомості про матеріальну базу денних закладів загальної середньої освіти та використання сучасних інформаційних технологій (без спеціальних шкіл (шкіл-інтернатів), навчально-реабілітаційних центрів)», Д-5 «Відомості про профільне навчання і поглиблене вивчення предметів у денних закладах загальної середньої освіти», Д-6 «Відомості про групування денних закладів загальної середньої освіти за кількістю класів і учнів та про наповнюваність класів учнями (без спеціальних шкіл (шкіл-інтернатів), навчально-реабілітаційних центрів)», Д-7-8 «Відомості про мови навчання та вивчення мови як предмета у закладах загальної середньої освіти (без спеціальних шкіл (шкіл-інтернатів), навчально-реабілітаційних центрів)», Д-9 «Відомості про заклади загальної середньої освіти» [15]; 1-ДБШ «Звіт дитячого будинку, загальноосвітньої школи-інтернату (спеціальної загальноосвітньої школиінтернату) для дітей-сиріт та дітей, позбавлених батьківського піклування», 1-ДБШ-зведена «Зведений звіт дитячих будинків, загальноосвітніх шкіл-інтернатів (спеціальних загальноосвітніх шкіл-інтернатів) для дітей-сиріт та дітей, позбавлених батьківського піклування» [16]; 1-ПЗ «Звіт позашкільного навчального закладу», 1-ПЗ-зведена «Зведений звіт позашкільних навчальних закладів» [17]; 77-РВК «Звіт про кількість дітей шкільного віку» [18].
Розглянемо основні зміни, що внесені до форм статистичної звітності на початок 2018/2019 н. p.

Для забезпечення рівного доступу до якісної освіти дітей з сільської місцевості створена мережа опорних шкіл та їхніх філій, тому в статистичну форму 76-РВК введено новий розділ «Відомості про опорні заклади та їх філії» з такими показниками, як кількість опорних закладів та їх філій; кількість в них класів та учнів; дітей, які навчаються індивідуально, дистанційно; дітей з особливими освітніми потребами, у тому числі навчаються індивідуально, дистанційно, в інклюзивних класах, в спеціальних класах. Також добавлено інформацію щодо кількості закритих, відкритих та реорганізованих ЗЗСО.

Починаючи 3 2018/2019 н. р. 3 метою отримання повної, всебічної та об'єктивної статистичної інформації щодо кількості дітей шкільного віку, кількості дітей, які не навчаються для здобуття повної загальної середньої освіти, та причин, через які вони не відвідують 33СО, щорічно збиратиметься статистична інформація за формою № 77-РВК «Звіт про кількість дітей шкільного віку». Цей звіт складається відділами освіти районних/міських/обласних державних адміністрацій на підставі списків дітей та підлітків віком від 6 до 18 років і дітей, яким до 1 вересня виповнилося 5 років. Також відображаються дані щодо загальної кількості дітей та дітей 3 особливими освітніми потребами, які навчаються в закладах освіти для здобуття повної загальної середньої освіти, у тому числі у З3СО усіх ступенів, закладах професійної (професійно-технічної) освіти, вищої освіти та в інших закла- 
дах, а також інформація щодо дітей, які не навчаються для здобуття повної загальної середньої освіти, або про яких відсутні відомості.

До статистичної форми звітності 83-РВК «Зведений звіт про чисельність і склад педагогічних працівників закладів загальної середньої освіти» внесено показники про кількість ставок учителів 1-4-х класів; учителів 5-11 (12-х) класів; учителів музики, образотворчого мистецтва, фізкультури, захисту Вітчизни, трудового навчання; директорів закладів та їх заступників; практичних психологів, соціальних педагогів, асистентів в інклюзивних класах, вихователів, які не викладають предмети в закладах, педагогів-організаторів, учителів, директорів, заступників директорів, вихователів (які викладають і не викладають предмети), педагогів-організаторів у закладах і класах для дітей 3 особливими потребами, дефектологів-спеціалістів; учителів у логопедичних пунктах. Також у розділі «Розподіл учителів, які викладають окремі предмети (включаючи директорів закладів та їх заступників)» за освітньо-кваліфікаційним рівнем освіти із загальної кількості учителів виокремлено показник із них жінок.

На початок 2018/2019 н. р. до зведеної таблиці Д-4 «Відомості про матеріальну базу денних закладів загальної середньої освіти та використання сучасних інформаційних технологій (без спеціальних шкіл (шкіл-інтернатів), навчально-реабілітаційних центрів) на початок навчального року» добавлено нові показники про види благоустрою опорних закладів та їх філій, а саме: кількість закладів, які мають центральне опалення або власну котельню, пічне опалення, водогін (у тому числі з гарячою водою), каналізацію, їдальню або буфет з гарячим харчуванням, а також забезпеченість опорних закладів технічними засобами навчання.

У зв'язку із стрімким розвитком інформаційних технологій все більшої актуальності набуває формування інформаційної культури сучасних школярів. Сьогодні впровадження комп'ютерних технологій у навчальний процес $є$ невід'ємною частиною шкільного навчання. Використання комп'ютерних технологій в освіті істотно підвищує ефективність та якість навчання. Для висвітлення стану використання сучасних інформаційних технологій З3СО до форми Д-4 внесено нові показники в розділ «Відомості про використання сучасних інформаційних технологій» а саме: заклади, підключені до WiFi; заклади, які мають класи з інтерактивними поверхнями; заклади, які мають класи із засобами візуалізації; заклади, які мають принтери, фотоапарати, відеокамери, верстати 3 числовим програмним управлінням; заклади з технологією, за якою надається доступ до мережі Інтернет (широкосмуговий доступ, технології бездротового доступу та швидкості підключення до Інтернету).

Діти 3 особливими освітніми потребами в інклюзивних та спеціальних класах 33 со та діти 3 інвалідністю потребують використання корекційних засобів навчання та реабілітаційного обладнання для дітей 3 тяжкими порушеннями мовлення, опорно-рухового апарату, слуху, зору тощо. Інформація про ці засоби, їх наявність відображається у формі Д-4 нового розділу «Відомості про 
використання корекційних засобів навчання та реабілітаційного обладнання».

Детального висвітлення потребує матеріальна база закладів спеціальної освіти, тому форму статистичної звітності Д-9 «Відомості про заклади спеціальної освіти» доповнено новим розділом «Відомості щодо приміщення та матеріальної бази закладів спеціальної освіти». Цей розділ включає показники про загальну площу приміщень, класних кімнат, відомості про наявність фізкультурної зали, басейну, центрального опалення, водогону, каналізації, їдальні або буфета з гарячим харчуванням, безперешкодного доступу учнів 3 інвалідністю до поверхів (першого, другого і т. д.), обладнання для дітей 3 тяжкими порушеннями мовлення, опорно-рухового апарату, зору, бібліотечний фонд, використання корекційних засобів навчання та реабілітаційного обладнання тощо.

Розглядаючи статистичний документообіг як системний процес, можна виділити такі його основні атрибути, як реквізитний склад документів, структура документів (сукупність взаємозв'язків між реквізитами документів), структура документообігу (сукупність взаємозв'язків між самими документами або схема документообігу), технологія обробки документів. Визнаючи важливість всіх складових процесу документообігу, підкреслимо, що за умов його удосконалення на основі інформаційно-комунікаційних технологій головним $\epsilon$ питання розподіленої за організаційними рівнями управління освітою технологія обробки документів, що повинна враховувати особливості процесу формуван- ня складу й структури статистичної звітності на кожному з цих рівнів. Нині для керівників районного та обласного рівнів якісне інформаційно-аналітичне забезпечення, основу якого складає статистична звітність, $\epsilon$ необхідною умовою підвищення ефективності управління регіональними системами освіти [1]. Як показав аналіз, найбільш напруженим і трудомістким в технології обробки статистичної звітності $€$ районний рівень управління освітою, де відбувається найскладніший з технологічної точки зору процес опрацювання інформації - це процес формування 3 первинної статистичної звітності за формою 3НЗ-1 усіх регламентованих статистичних форм звітності районного рівня управління. На обласному рівні управління з цих статистичних звітів шляхом простого сумування даних районних звітів формуються обласні статистичні звіти за кожною із зазначених форм (рис. 1).

У 2016 р. відповідно до наказу МОН від 31.08.2016 № 1054 [19] введено в дослідну експлуатацію Державну інформаційно-телекомунікаційну систему освіти (ДІСО), згідно якого З3СО подають первинні форми статистичної звітності (ЗН3-1, ЗН3-2, 83-РВК) до цієї системи в електронному вигляді. Місцеві відділи/ управління/департаменти освіти i науки контролюють процес введення даних, перевіряють дані на достовірність та формують зведені статистичні звіти (76-РВК, Д-4, Д-5, Д-6, Д-7-8, Д-9, 1-3В, 83-РВК). ДІСО містить механізми, необхідні для збору, збереження, виробництва і використання інформації, що забезпечують точність, безпеку та своєчасну якісну інформацію для використання при 


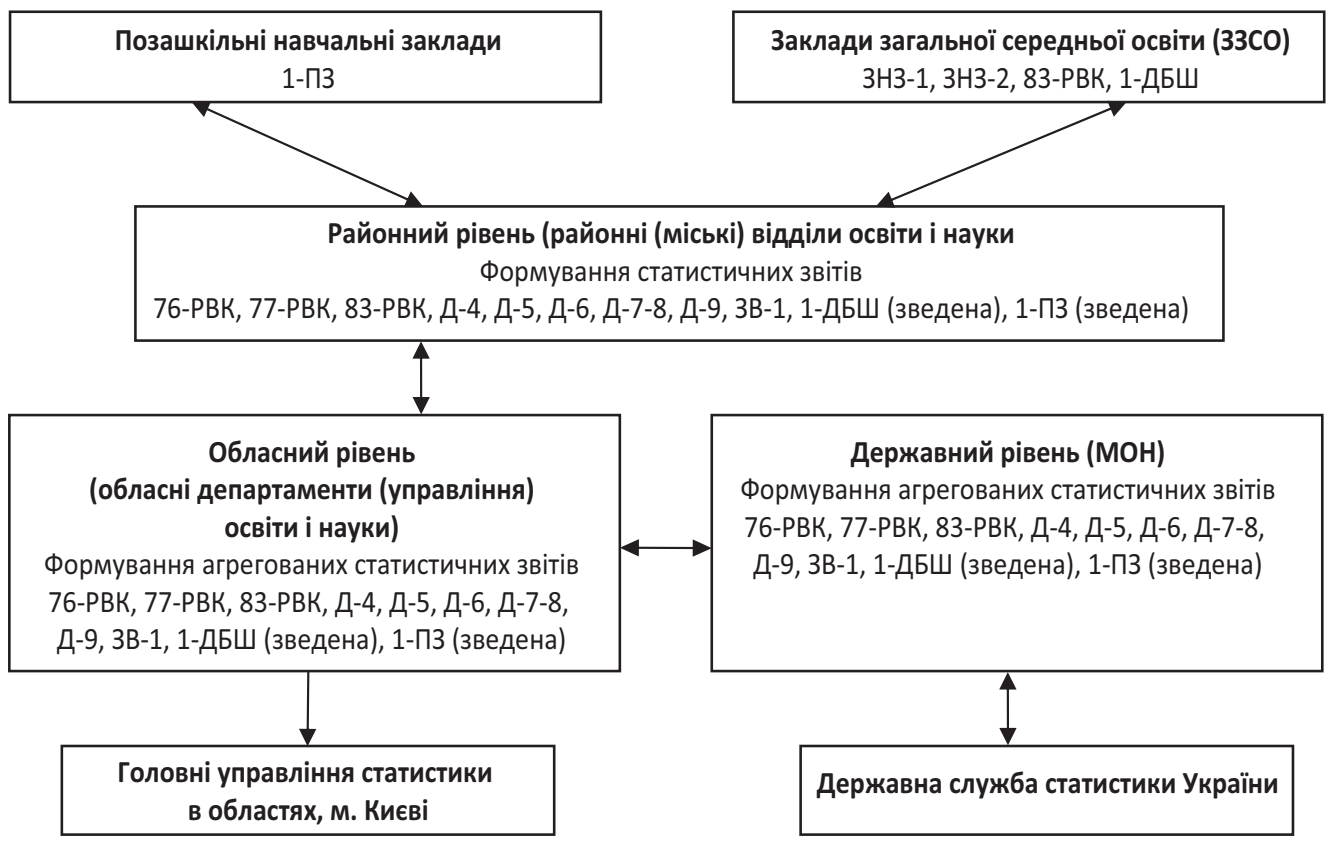

Рис. 1. Схема формування статистичної звітності закладів загальної середньої та позашкільної освіти

Побудовано авторами на основі нормативно-правових документів.

прийнятті управлінських рішень 3 питань загальної середньої освіти.

Для формування зведених галузевих звітів на державному рівні та подання їх до Державної служби статистики України (ДССУ) створено прикладну інформаційно-аналітичну систему, яка використовує зведені дані на обласному рівні та забезпечує комп'ютерну технологію узгодження й аналізу показників, формування розрахункових аналітичних показників, підготовку інформаційних бюлетенів, статистичних збірників.

До Державної служби статистики України МОН подає зведені звіти в паперовому вигляді, а також в електронному форматі (*.xls) в розрізі регіонів за всіма показниками відповідних форм статистичної звітності.

Розроблена система узгодження показників у формах статистичної звітності передбачає арифметичний та логічний контролі в межах одного розділу статистичної форми звітності, між окремими розділами та окремими формами і представляється у вигляді математичних формул та виразів.

Інформаційна база даних - це уніфікована сукупність даних, що накопичуються, зберігаються та відтворюються в рамках комп'ютеризованої системи. Система керування базами даних (СКБД) поєднує відомості 3 різних джерел в одній реляційній базі даних [20]. Створені форми, запити і звіти дозволяють швидко й ефективно оновлювати дані, здійснювати пошук потрібної інформації, здійснювати аналіз даних, друкувати звіти, діаграми тощо.

Метою побудови інфологічної моделі $€$ побудова структурованої 
інформаційної моделі комп'ютерної системи, створення схеми інформаційної бази даних у формі однієї або декількох локальних моделей. У подальшому вони перетворюються в будь-яку модель даних - реляційну, ієрархічну або мережеву [20].

Форми статистичної звітності, що опрацьовуються на рівні галузі освіти, мають такі загальні характеристики:

- складаються з розділів;

- показники розміщені в рядках та графах;

- період подання звітів - щорічно (на початок навчального або календарного року);

- подаються обласними управліннями/департаментами освіти і науки;

- форма власності та підпорядкування 33С0;

- тип місцевості, де розміщено ЗЗСО (міська, сільська).

Зазначимо, що показники статистичних форм $є$ абсолютними значеннями, при цьому можуть бути використані для обрахунку аналітичних показників, які більш конкретно характеризують галузь, наприклад, середня наповнюваність учнями закладу або класу, середня кількість учнів у 5-х класах в сільській місцевості, кількість учнів на один комп'ютер або на одне робоче комп'ютеризоване місце, кількість підручників на 100 учнів тощо. Ці показники називаються розрахунковими. Різноманітність показників визначається запитами користувачів до інформаційної бази даних, які програмними засобами автоматично перетворюються у формалізовані запити до інформаційної бази даних.

Стандартною мовою для обробки запитів у більшості програмних пакетів СКБД є SQL, яка надає користувачу широкий набір операторів і готових функцій, що дозволяють проводити різні маніпуляції 3 локальними і віддаленими базами даних, здійснювати пошук, сортування та формування необхідної інформації. У такий спосіб система запитів дозволяє через вибір значень відповідних показників отримати інформацію щодо будь-якого об'єкта бази даних. Відповідно до вище викладеного побудовано схему запитів користувачів інформації до бази даних (рис. 2). Наведена схема $є$ основою для розробки системи запитів, що уможливлюють отримання інформації за певними ознаками об'єкта, та проектування схеми представлення інформації, шаблонів звітів і вихідних таблиць.

На основі цієї структури запитів розроблено інфологічну схему інформаційної бази даних, яка приведена на рис. 3 .

Комп'ютерна система має в своєму складі підсистему вводу інформації, яка може бути організована як ручне введення користувачами інформації, або як імпортування вхідної інформації, надісланої обласними департаментами/управліннями освіти і науки в заданому форматі (наприклад, це можуть бути файли електронних таблиць MS Excel).

Наступна підсистема повинна виконувати процедури обчислення розрахункових показників та рейтингових індикаторів. Обчислення здійснюється відповідно до формул, які описуються у відповідних довідниках.

Для підсистем формування статистичних збірників, інформаційних бюлетенів та інформаційно-аналі- 

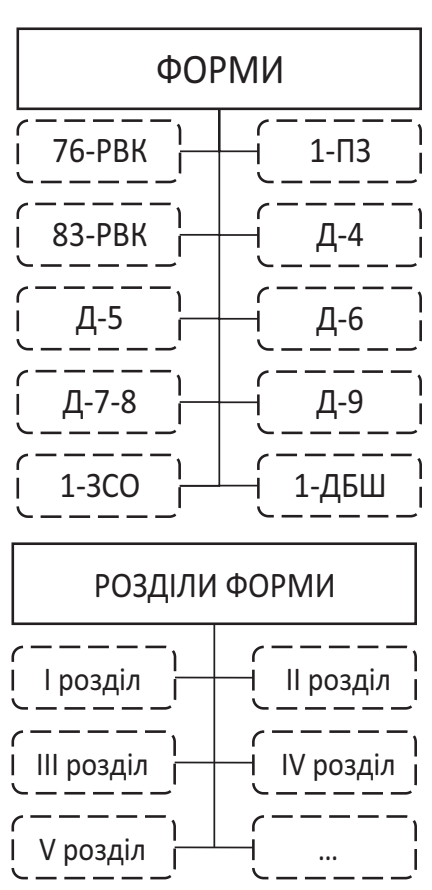
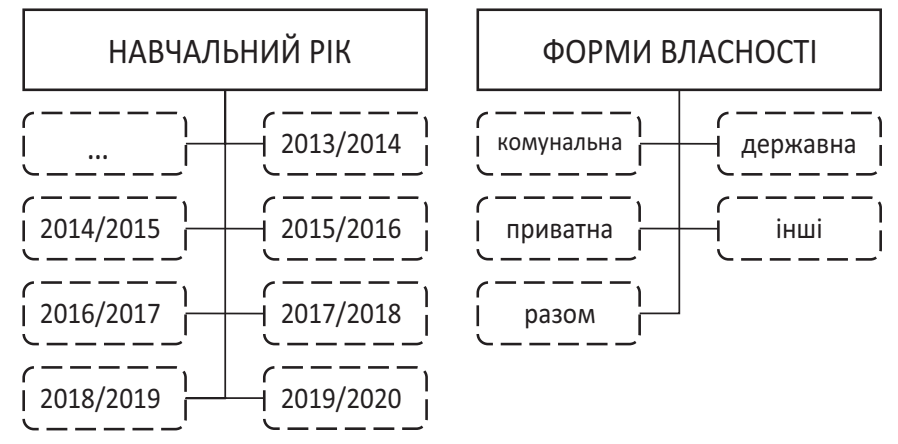
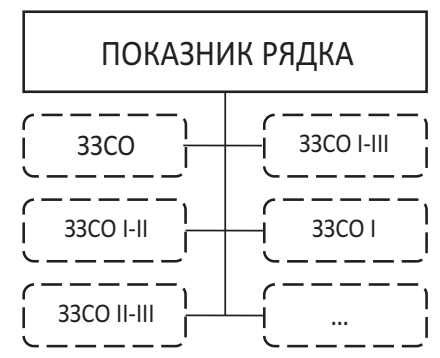

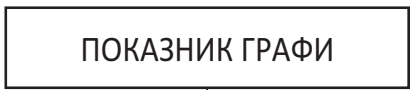

г--- - -

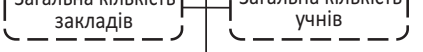
(Загальна кількість $\quad$ Загальна кількість Загальна кількість
учителів $\underset{\text { гімназій }}{\text { Загальна кількість }}$ ( - учителів - ( Загальна кількість

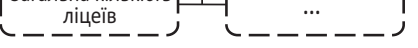
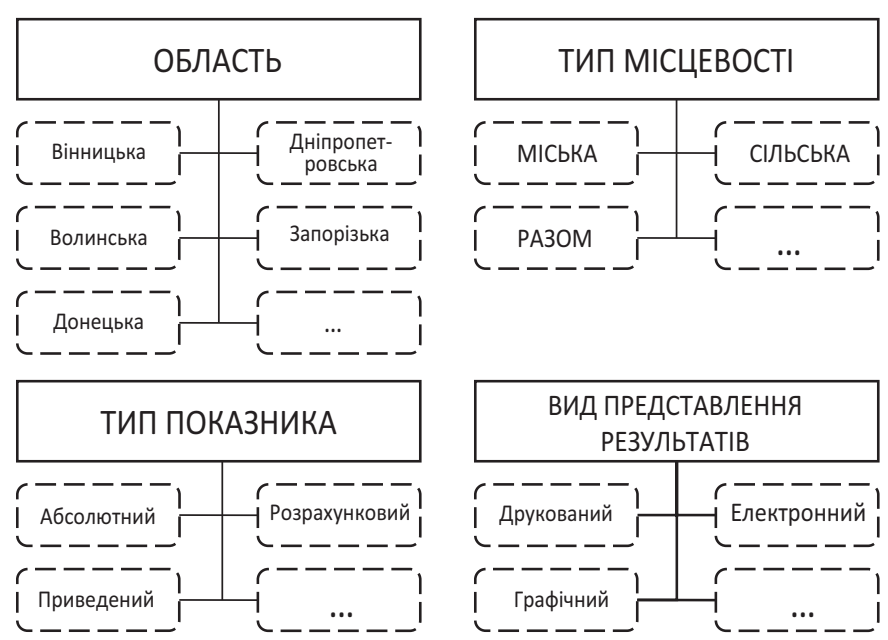

Рис. 2. Структура запитів до інформаційної бази даних

Побудовано авторами.

тичних збірників 3 рейтинговими індикаторами потрібно передбачити такі функції для користувачів:

- створення структури збірника (назва, тематика, розділи збірника);

- обрання періодів (декілька навчальних років) для порівняння показників;
- визначення розрізів та направленості відображення інформації (загальні дані в розрізі областей, з поділом на міську та сільську місцевості);

- визначення переліку абсолютних та/або розрахункових показників, що будуть відібрані із вже сфор- 


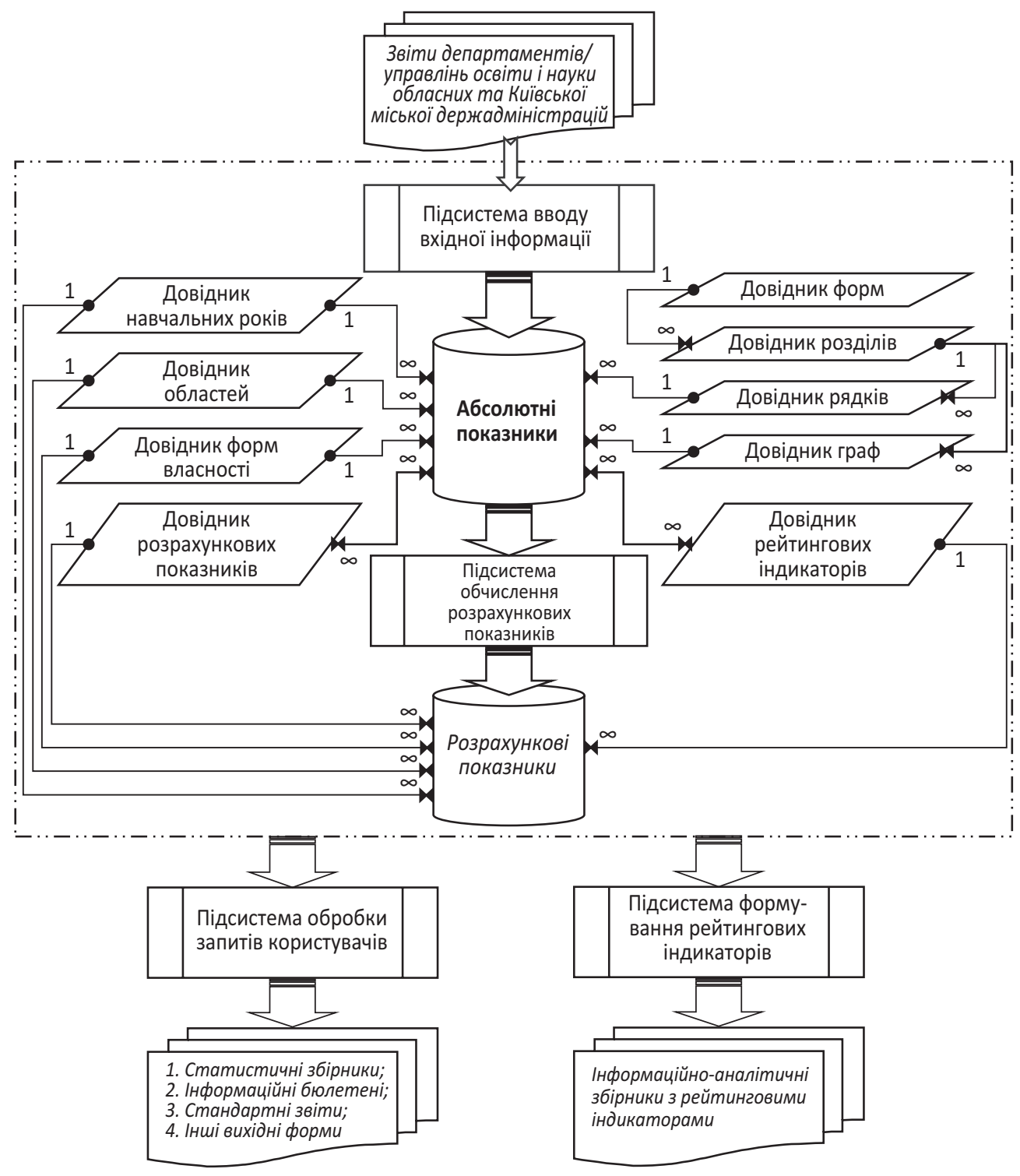

\section{Рис. 3. Інфологічна схема бази даних}

Побудовано авторами.

мованої інформаційної бази даних, за розділами збірника;

- створення нових розрахункових показників із визначенням назви, формули обрахунку та показників які приймають участь в обрахунку;

- обрання форми представлення інформації - у вигляді інформаційно- аналітичних таблиць або аналітично-графічних матеріалів.

Схема формування інформаційних збірників зображена на рис. 4 .

Підсистеми обробки запитів користувачів та формування рейтингових індикаторів призначені для кінцевих користувачів (МОН, ДНУ 


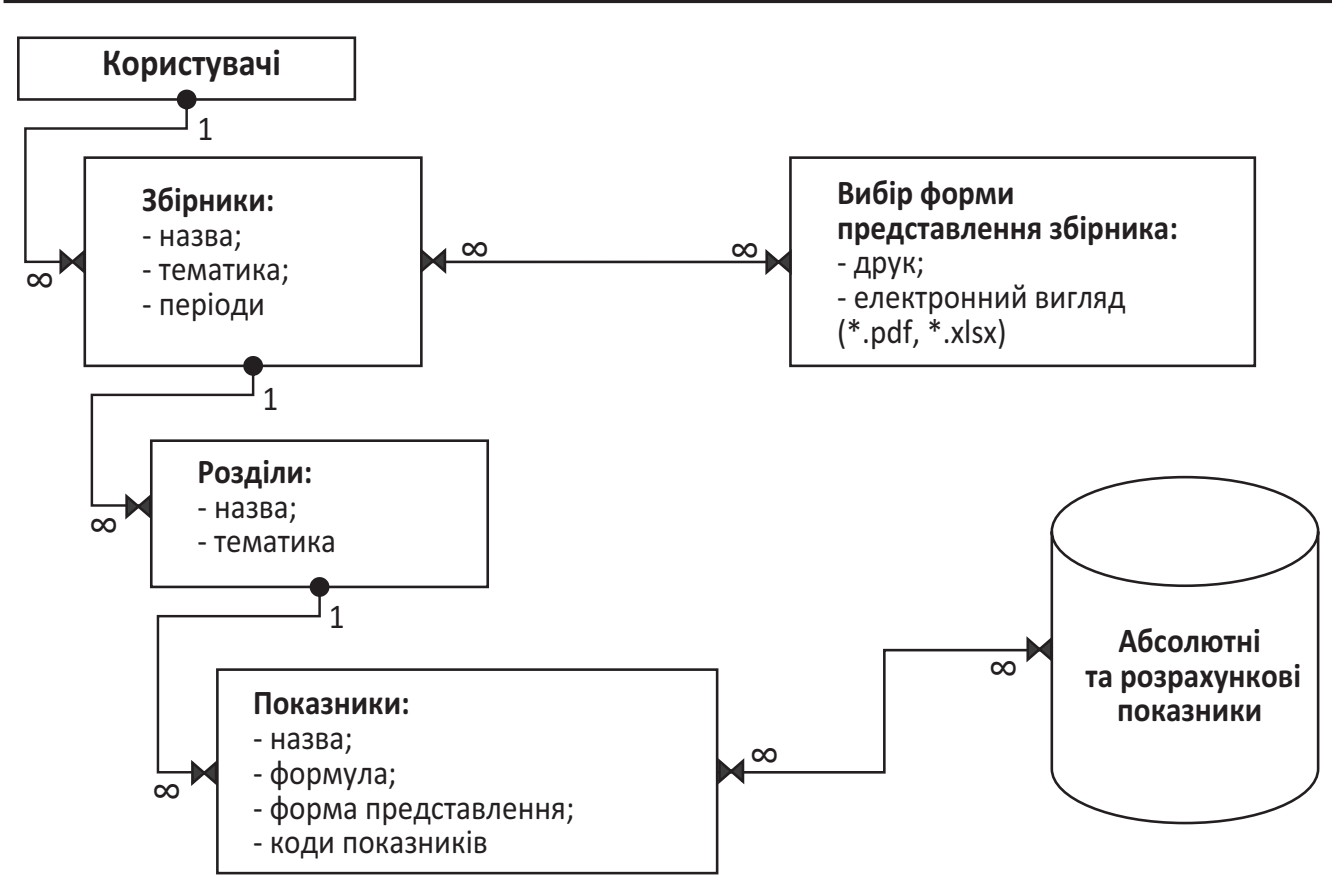

Рис. 4. Схема формування інформаційних збірників

Побудовано авторами

«Інститут освітньої аналітики», обласні департаменти/управління освіти і науки). За допомогою цих підсистем користувачі відповідно до своїх регламентованих або нерегламентованих запитів отримують інформацію в розрізах та у визначеному користувачем вигляді (на екрані, в електронному вигляді формату MS Excel або Adobe Reader, в друкованому вигляді). Передбачено також формування зведених галузевих звітів, статистичних збірників, інформаційних бюлетенів, збірників з рейтинговими індикаторами.

На початок 2018/2019 н. p. розроблено вісім інформаційних бюлетенів, які розміщені на сайті ДНУ «Інститут освітньої аналітики»:

1. «Заклади загальної середньої освіти Міністерства освіти і науки
України, інших міністерств і відомств та приватні заклади (2017/2018н. р. та 2018/2019 н. р.)».

2. «Про чисельність і склад педагогічних працівників закладів загальної середньої освіти Міністерства освіти і науки України, інших міністерств і відомств та приватних закладів $(2017 / 2018$ н. р. та 2018/2019 н. р.)».

3. «Відомості про матеріальну базу та використання сучасних інформаційних технологій в денних закладах загальної середньої освіти Міністерства освіти і науки України, інших міністерств і відомств та приватних закладах (2017/2018 н. р. та 2018/2019 н. р.)».

4. «Відомості про профільне і поглиблене вивчення предметів у денних закладах загальної середньої освіти Міністерства освіти і 
науки України, інших міністерств і відомств та приватних закладах (2017/2018 н. р. та 2018/2019 н. р.)».

5. «Відомості про групування денних закладів загальної середньої освіти за кількістю класів і учнів та наповнюваність класів учнями у денних закладах загальної середньої освіти Міністерства освіти і науки України, інших міністерств і відомств та приватних закладах (2017/2018 н. р. та 2018/2019 н. р.)».

6. «Відомості про мови навчання та вивчення мови як предмета у закладах загальної середньої освіти Міністерства освіти і науки України, інших міністерств і відомств та приватних закладах (2017/2018 н. р. та 2018/2019 н. р.)».

7. «Санаторні та спеціальні школи (школи-інтернати) державної і комунальної форм власності Міністерства освіти і науки України та приватної форми власності (2017/2018 н. р. та 2018/2019 н. p.)».

8. «Позашкільні навчальні заклади Міністерства освіти і науки України (станом на 01.01.2018 та 01.01.2019)».

Отже, розроблена інформаційноаналітична система опрацюван- ня форм статистичної звітності загальної середньої освіти забезпечує структурні підрозділи Міністерства освіти і науки України аналітичною інформацією щодо стану діяльності закладів на обласному та державному рівнях. Ця система підвищує ефективність прийняття управлінських рішень, якість взаємодії з Державною службою статистики України в частині правильності, прозорості та достовірності поданих статистичних звітів, а також уможливлює прогнозування показників на певний період (наприклад, контингент учнів, кількість першокласників, наповнюваність шкіл, класів, випуск учнів, кількість педагогічного персоналу, кошти із державного бюджету на утримання одного учня, одного класу тощо).

Запропоноване інформаційноаналітичне забезпечення - це крок до оцінювання результативності діяльності кожного регіону, надання можливості інформувати суспільство про стан, динаміку та розвиток загальної середньої освіти і рівень досягнень в освітній, навчально-виховній та фінансовій сферах, зайняття певних позицій на ринку освітніх послуг.

\section{Список використаних джерел}

1. Биков В. Ю., Гапон В. В., Плескач М. М. Розвиток структури комп'ютерних систем опрацювання статистичної звітності для забезпечення управління освітою. Комп'ютер у школі та сім'ї. 2005. № 3. С. 3-6.

2. Герасименко С. С., Головач А. В., Єріна А. М. Статистика : підручник. Київ : КНЕУ, 2000. 467 c.

3. Головач $A$. B. Статистичне забезпечення управління економікою: прикладна статистика : навч. посіб. Київ : КНЕУ, 2005. 334 с.

4. Ляшенко О. Організаційно-методичне забезпечення моніторингових досліджень якості загальної середньої освіти : монографія. Київ : Педагогічна думка, 2011.160 с.

5. Осауленко О. Г. Національна статистична система: стратегічне планування, методологія та організація : монографія. Київ : ДП «Інформаційно-аналітичне агентство», 2008. $415 \mathrm{c}$. 
6. Моніторинг якості освіти: світові досягнення та українські перспективи / за заг. ред. О. Локшиної. Київ : К.І.С., 2004. 128 с.

7. Лукіна Т. О. Моніторинг якості освіти: теорія і практика. Київ : Вид. дім «Шкільний світ». Вид. Л. Голіцина, 2006. 128 с.

8. Про освіту : Закон України від 05.09.2017 р. № 2145-VIII. URL: http://zakon2.rada. gov.ua/laws/show/2145-19.

9. Про державну статистику : Закон України від 17.09.1992 р. № 2614-XII. URL: http://zakon2.rada.gov.ua/laws/show/2614-12.

10. Про загальну середню освіту : Закон України від 13.05.1999 р. № 651-XIV. URL: http://zakon2.rada.gov.ua/laws/show/651-14.

11. Про національну стратегію розвитку освіти в Україні на період до 2021 року : Указ Президента України від 25.06.2013 р. № 344/2013. URL: http://zakon2.rada.gov. ua/laws/show/344/2013.

12. Про затвердження форм звітності з питань діяльності денних закладів загальної середньої освіти та інструкцій щодо їх заповнення : наказ Міністерства освіти і науки України від 27.08.2018 р. № 936. URL: https://zakon.rada.gov.ua/laws/main/ z1000-18.

13. Інструкція щодо заповнення форми звітності № 3В-1 «Зведений звіт вечірніх (змінних) шкіл» : наказ Міністерства освіти і науки, молоді та спорту України від 02.07.2012 p. № 766. URL: https://zakon2.rada.gov.ua/laws/show/z1211-12.

14. Про затвердження форми звітності щодо чисельності та складу педагогічних працівників закладів загальної середньої освіти та інструкції щодо ії заповнення : наказ Міністерства освіти і науки України від 27.08.2018 p. № 937. URL: https://zakon. rada.gov.ua/laws/main/z0997-18.

15. Про затвердження зведених таблиць з питань загальної середньої освіти : наказ Міністерства освіти і науки України від 03.10.2018 p. № 1062. URL: https://mon. gov.ua/ua/npa/pro-zatverdzhennya-zvedenih-tablic-z-pitan-zagalnoyi-serednoyi-osviti.

16. Про затвердження форм звітності з питань діяльності дитячих будинків і загальноосвітніх (спеціальних) шкіл-інтернатів для дітей-сиріт та дітей, позбавлених батьківського піклування, та інструкцій щодо їх заповнення : наказ Міністерства освіти і науки України від 25.11.2009 р. №1064. URL: https://zakon2.rada.gov.ua/laws/ show/z1224-09.

17. Про затвердження форм звітності з питань діяльності позашкільних навчальних закладів та інструкцій щодо їх заповнення : наказ Міністерства освіти і науки України від 12.07.2017 р. № 1016. URL: https://zakon.rada.gov.ua/laws/main/z0954-17.

18. Про затвердження форми звітності про кількість дітей шкільного віку та інструкції щодо її заповнення : наказ Міністерства освіти і науки України від 27.08.2018 p. № 938. URL: https://zakon.rada.gov.ua/laws/main/z0998-18.

19. Про введення в дослідну експлуатацію інформаційно-телекомунікаційної системи державної наукової установи «Інститут освітньої аналітики» «Державна інформаційна система освіти» : наказ Міністерства освіти і науки України від 31.08.2016 p. № 1054. URL: http://diso.gov.ua/upload/Nakaz_1054.PDF.

20. Степанов В. П., Пономаренко $Є$. В. Організація баз даних та знань : підручник. Ч. 1. Харків, 2013. 485 с. 


\title{
Valentyna Gapon
}

Ph. D. (Pedagogical Sciences), SSI «Institute of Educational Analytics», Kyiv, Ukraine, gapon@mon.gov.ua ORCID ID: https://orcid.org/0000-0001-7521-5450

\section{Olena Barabash}

SSI «Institute of Educational Analytics», Kyiv, Ukraine, o_barabash@mon.gov.ua ORCID ID: https://orcid.org/0000-0003-2545-0369

\section{INFORMATION AND ANALYTICAL SUPPORT FOR THE FORMATION AND ANALYSIS OF STATISTICAL INDICATORS OF GENERAL SECONDARY EDUCATION}

\begin{abstract}
The authors investigate regulatory documents for the collection and processing of sectoral statistical reporting, developed a system of harmonization of indicators of statistical forms, which provides arithmetic and logical controls within one section of the statistical reporting form, between separate sections and separate forms, and is presented in the form of mathematical formulas and expressions. It is determined that a detailed analysis of the state of secondary education requires information and analytical support, developed on the basis of uniform methodological principles for the organization of statistical observation, which will ensure not only the resolution of individual issues and control the implementation of the proposed measures, but also any analytical research depending on the tasks set. The structure of the information base and the tools for forming the consolidated sectoral statistical reporting for submission to the State Statistics Service of Ukraine have been developed. The basic directions of qualitative changes in information support and improvement of the structure and content of primary statistical reporting from education institutions, the introduction of information and telecommunication technologies and the creation of unified information support are determined. It is proved that the proposed mechanisms for collecting, processing, storing and using statistical information provide accuracy, security and timely analytical information for use in decision making on general secondary education. The system provides the possibility of rapid monitoring of the activities of general secondary education institutions, contains adjustment procedures for adaptation to changes in statistical reporting forms, preparation of information and analytical materials in various sections (areas, reporting forms, separate statistical and analytical indicators, dynamics by years, etc.) newsletters on the state of general secondary education by area (network of general secondary education institutions, pedagogical staff, profile training, languages training and language as a subject, logistics and the use of modern information technology, special education institutions, etc.).
\end{abstract}

Keywords: general secondary education, general secondary education institution, statistical reporting, statistical index, information-analytical support.

\section{References}

1. Bykov, V. Yu., Hapon, V. V., Pleskach, M. M. (2005). The development of the structure of computer systems for processing statistical reports to ensure education management. Kompiuter u shkoli ta simi, No. 3, 3-6 [in Ukrainian].

2. Herasymenko, S. S., Holovach, A. V., Yerina, A. M. (2000). Statistics: a textbook. Kyiv: KNEU, 467 [in Ukrainian].

3. Golovach, A. V. (2005). Statistical support for economic management: applied statistics: a textbook. Kyiv: KNEU, 334 [in Ukrainian]. 
4. Liashenko, 0. (2011). Organizational and methodological support of monitoring studies of the quality of general secondary education: monograph. Kyiv: Pedahohichna dumka,160 [in Ukrainian].

5. Osaulenko, O. H. (2008). National statistical system: strategic planning, methodology and organization: monograph. Kyiv: DP «Informatsiino-analitychne ahentstvo», 415 [in Ukrainian].

6. Lokshyna, 0. (Ed.) (2004). Monitoring the quality of education: world achievements and Ukrainian perspectives. Kyiv: K.I.S., 128 [in Ukrainian].

7. Lukina, T. O. (2006) Monitoring quality of education: theory and practice. Kyiv: Vyd. dim «Shkilnyi svit». Vyd. L. Holitsyna, 128 [in Ukrainian].

8. Verkhovna Rada of Ukraine. (2017). About education (Act No. 2145-VIII, September 5). Retrieved from http://zakon2.rada.gov.ua/laws/show/2145-19 [in Ukrainian].

9. Verkhovna Rada of Ukraine. (1992). On state statistics (Act No. 2614-XII, September 17). Retrieved from http://zakon2.rada.gov.ua/laws/show/2614-12 [in Ukrainian].

10. Verkhovna Rada of Ukraine. (1999). On general secondary education (Act No. 651-XIV, May 13). Retrieved from http://zakon2.rada.gov.ua/laws/show/651-14 [in Ukrainian].

11. President of Ukraine. (2013). National strategy for the development of education in Ukraine for the period up to 2021 (Order No. 344/2013, June 25). Retrieved from https:// zakon.rada.gov.ua/laws/show/344/2013 [in Ukrainian].

12. Ministry of Education and Science of Ukraine. (2018). On approval of reporting forms on activities of daytime general education institutions and instructions for their completion (Order No. 936, July 27). Retrieved from https://zakon.rada.gov.ua/laws/main/z1000-18 [in Ukrainian].

13. Ministry of Education and Science, Youth and Sports of Ukraine. (2012). Instruction on filling the report form № ZV-1 «Consolidated report of evening (part time) schools» (Order No.766, July 2). Retrieved from https://zakon2.rada.gov.ua/laws/show/z1211-12 [in Ukrainian].

14. Ministry of Education and Science of Ukraine. (2018). On approval of reporting form on the number and composition of pedagogical staff of general secondary education institutions and instructions for its completion (Order No. 937, August 27). Retrieved from https://zakon. rada.gov.ua/laws/main/z0997-18 [in Ukrainian].

15. Ministry of Education and Science of Ukraine. (2018). On approval of summary tables on general secondary education (Order No. 1062, October 3). Retrieved from https://mon. gov.ua/ua/npa/pro-zatverdzhennya-zvedenih-tablic-z-pitan-zagalnoyi-serednoyi-osviti [in Ukrainian].

16. Ministry of Education and Science of Ukraine. (2009). On approval of reporting forms on the activities of orphanages and general (special) boarding schools for orphans and children deprived of parental care and instructions for its completion (Order No. 1064, November 25). Retrieved from https://zakon2.rada.gov.ua/laws/show/z1224-09 [in Ukrainian].

17. Ministry of Education and Science of Ukraine. (2017). On approval of reporting forms on the activities of out-of-school education institutions and instructions for its completion (Order No. 1016, July 12). Retrieved from https://zakon.rada.gov.ua/laws/main/z0954-17 [in Ukrainian].

18. Ministry of Education and Science of Ukraine. (2018). On approval of reporting forms on the the number of school-age children and instructions for its completion (Order No. 938, August 27). Retrieved from https://zakon.rada.gov.ua/laws/main/z0954-17 [in Ukrainian].

19. Ministry of Education and Science of Ukraine. (2016). On introduction into test operation the information and telecommunication system of the State Scientific Institution «Institute of Educational Analytics» «State information system of education (Order No.1054, August 31). Retrieved from http://diso.gov.ua/upload/Nakaz_1054.PDF [in Ukrainian].

20. Stepanov, V. P., Ponomarenko, Ye. V. (2013). Organization of databases and knowledge: a textbook. $1^{\text {st }}$ ed., Kharkiv, 485 [in Ukrainian]. 